\title{
The Determination of Defective Particle Fraction in HTGR Fuels
}

\author{
D. E. LaValle \\ D. A. Costanzo \\ W. J. Lackey \\ A. J. Caputo
}




\section{DISCLAIMER}

This report was prepared as an account of work sponsored by an agency of the United States Government. Neither the United States Government nor any agency Thereof, nor any of their employees, makes any warranty, express or implied, or assumes any legal liability or responsibility for the accuracy, completeness, or usefulness of any information, apparatus, product, or process disclosed, or represents that its use would not infringe privately owned rights. Reference herein to any specific commercial product, process, or service by trade name, trademark, manufacturer, or otherwise does not necessarily constitute or imply its endorsement, recommendation, or favoring by the United States Government or any agency thereof. The views and opinions of authors expressed herein do not necessarily state or reflect those of the United States Government or any agency thereof. 


\section{DISCLAIMER}

Portions of this document may be illegible in electronic image products. Images are produced from the best available original document. 


\section{Printed in the United States of America. Available from National Technical Information Service \\ U.S. Department of Commerce \\ 5285 Port Royal Road, Springfield, Virginia 22161 \\ Price: Printed Copy $\$ 4.00$; Microfiche $\$ 2.25$ \\ 3,52}

This report was prepared as an account of work sponsored by the United States Government. Neither the United States nor the Energy Research and Development Administration/United States Nuclear Regulatory Commission, nor any of their employees, nor any of their contractors, subcontractors, or their emplovees, makes any warranty, express or implied, or assumes any legal liability or responsibility for the accuracy, completeness or usefulness of any information, apparatus, product or process disclosed, or represents that its use would not infringe privately owned rights. 
Contract No. W-7405-eng-26

ANALYTICAL CHEMISTRY DIVISION

THORIUM UTILIZATION PROGRAM (189a OH045)

Fuel Refạbrication Development - Task 300

\section{THE DETERMINATION OF DEFECTIVE PARTICLE FRACTION IN HTGR FUELS}

D. E. LaValle

D. A. Costanzo

W. J. Lackey*

A. 1. Caputo*

*Metals and Ceramics Division

Date Published: November 1976

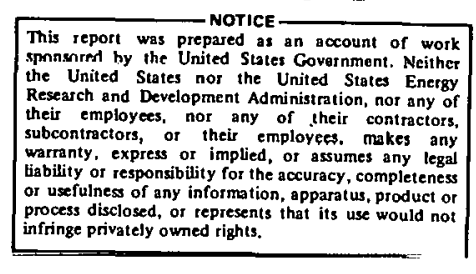

sho report was prepared as an account of work the United States nor the United States Energy Research and Development Administmation, not any or subcontractors, of their tiability or responsibility forthe of assumes any legal or usefulness of any information, apparatus, product or infringe privately owned rights.

NOTICE This document contains information of a preliminary nature and was prepared primarily for internal use at the Oak Ridge National Laboratory. It is subjact to revision or correction and therefore does not represent a final report.

OAK RIDGE NATIONAL LABORATORY

Oak Ridge, Tennessee 37830 operated by UNION CARBIDE CORPORATION

for the

ENERGY RESEARCH AND DEVELOPMENT ADMINISTRATION 
THIS PAGE

WAS INTENTIONALLY

LEFT BLANK 
CONTENTS

Page

ABSTRACT . . . . . . . . . . . . . . . . . . . . . . . 1

1. INTRODUCTION . . . . . . . . . . . . . . . . . . . . 1

2. LOW TEMPERATURE CHLORINATION . . . . . . . . . . . . . . . . 5

3. HIGH TEMPERATURE CHLORINATION . . . . . . . . . . . . . . . 8

4. RESULTS AND DISCUSSION . . . . . . . . . . . . . . . 11

5. CONCLUSION . . . . . . . . . . . . . . . . . . . . . 14

6. ACKNOWLEDGMENTS . . . . . . . . . . . . . . . . . 17

7. REFERENCES .......................... . . 18 


\section{LIST OF TABLES}

$\underline{\text { Page }}$

Table 1. Thorium Removal by Simple Diffusion at $1500^{\circ} \mathrm{C}(1 / 2$ x 2 in. Rods).................. 13

Table 2. Thorium Removal by Flow-Through Methods $(1 / 2 \times 2$ in. Rods )................... . . 13

Table 3. Thorium Removal by Partial Flow-Through at $1500^{\circ} \mathrm{C}$ $(1 / 2 \times 2$ in. Rods $)$............. 15 
Fig. 1. High-Temperature Gas-Cooled Reactor Fuel Particles Illus trating the Biso- and Triso-Coated Design ...... . 2

Fig. 2. Apparatus for Chlorine Leach at $1000^{\circ} \mathrm{C}$. . . . . . . . 6

Fig. 3. Apparatus for Chlorine Leach at $1500^{\circ} \mathrm{C}$. . . . . . . . 9

Fig. 4. Graphite Sample Holder for Rods or Loose Particles and Graphite Wedge .............. . 10

Fig. 5. Chlorination of Fuel Rods at $1000^{\circ} \mathrm{C}$. . . . . . . 12

Fig. 6. Fuel Removal from Biso-Coated $\mathrm{ThO}_{2}$ Particles with Permeable Coatings $(60 \mathrm{x}) \ldots \ldots . . . . . . .16$ 


\title{
THE DETERMINATION OF DEFECTIVE PARTICLE
}

FRACTION IN HTGR FUELS

D. E. LaValle, D. A. Costanzo

W. J. Lackey,* and A. J. Caputo*

\begin{abstract}
The fuel for the High-Temperature Gas-Cooled Reactor (HTGR) consists of uranium and thorium species in the form of microspheres individually encapsulated in layers of pyrolytic carbon and silicon carbide. In the characterization of these particles, an important consideration is the fraction in a particular sample that may have defective coatings which would allow the release of gaseous and metallic fission products. A method for this determination, which has been in use for almost a decade, is the chlorine leach in which the gas is passed over the particles at $1000^{\circ} \mathrm{C}$, and the fuel that is exposed by coating defects is volatilized and collected as the heavy metal chlorides. However, when the particles have been bonded into a fuel rod, the removal of exposed fuel from particles in the intact rod requires long exposure times (16-50 hours). A much more rapid procedure (2-3 hours) is described in which the chlorination of fuel rods is done at $1500^{\circ} \mathrm{C}$. The method is also applicable to loose particles. Also described is an adaptation of the chlorine leach at $1000^{\circ} \mathrm{C}$ for the treatment of irradiated fuel rods in a hot cell.
\end{abstract}

\section{INTRODUCTION}

In the thorium cycle HTGR the fuel employed consists of two kinds of coated microspherical particles as shown in Fig. 1. The Triso-coated fissile particle consists of a fuel kernel composed of 50 to $70 \mu \mathrm{g}$ of highly

*Metals and Ceramics Division. 


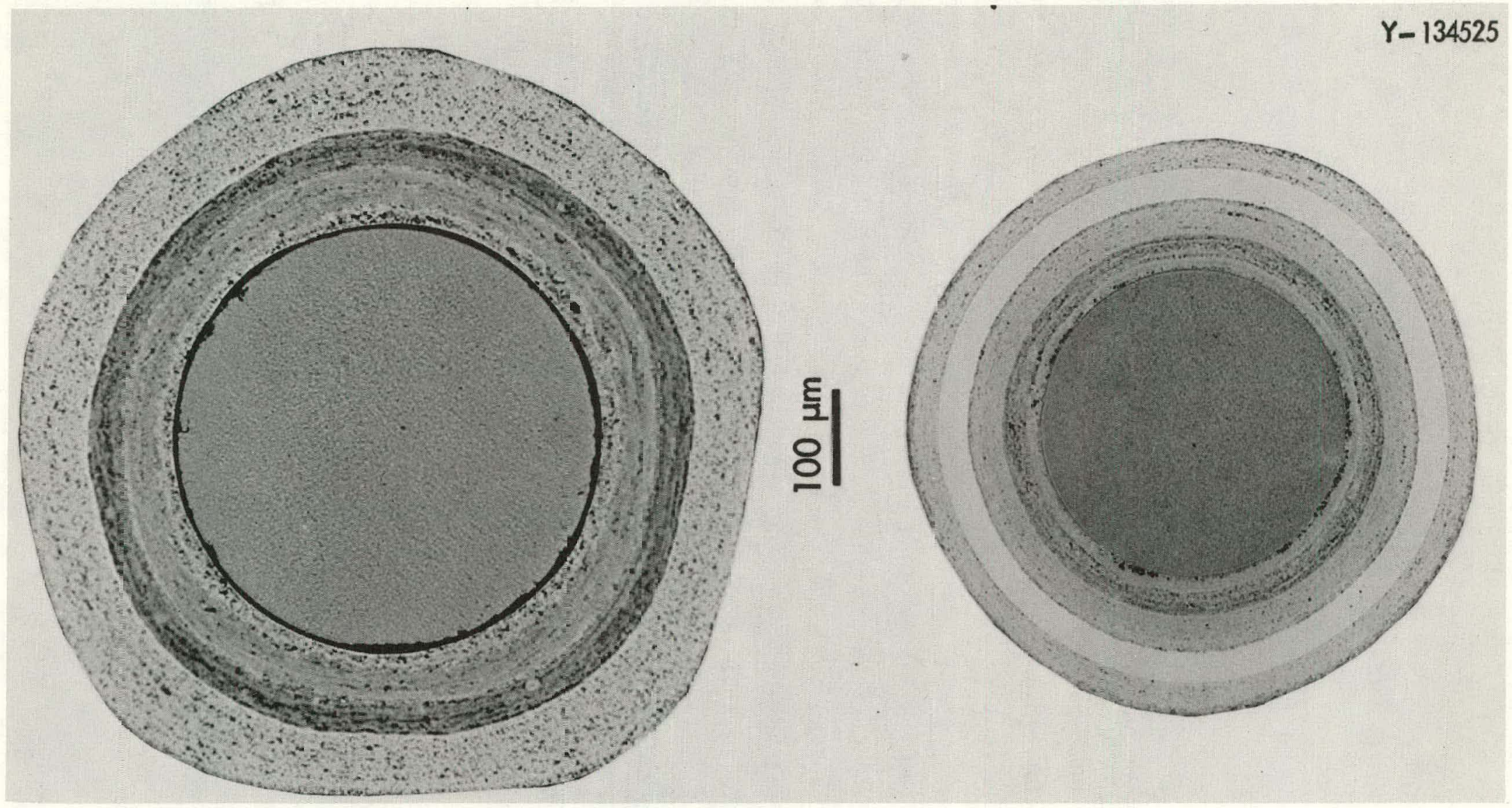

Fig. 1. High-Temperature Gas-Cooled Reactor Fuel Particles Illustrating the Biso- and Triso-Coated Design. 
enriched uranium as $\mathrm{UO}_{2}$ and $U \mathrm{CC}_{2}$. The kernel is enclosed in a multi-layered coating of porous buffer carbon, pyrolytic carbon, silicon carbide, and a final outer layer of dense pyrolytic carbon comprising a total coating thickness of 150 to $200 \mu \mathrm{m}$. The porous buffer coating of pyrolytic carbon provides void space for gaseous fission products and prevents damage to outer coatings by high energy fission fragments; the silicon carbide and dense pyrolytic carbon layers serve as containment vessels for retention of gaseous and metallic fission products. The Biso-coated fertile particle has a kernel of 400 to $500 \mu \mathrm{g}$ of thorium as $\mathrm{ThO}_{2}$, with a single layer of dense pyrolytic carbon around the inner porous pyrolytic carbon buffer coating. Using carbonaceous pitch and graphite flour, these separate particles are blended and bonded into fuel rods and are subsequently carbonized and annealed at $1800^{\circ} \mathrm{C}$. After fabrication of the particles and again after bonding into fue 1 rods, it is necessary to know the number with defective coatings that would allow the release of gaseous metallic fission products to the reactor cooling system. A typical fuel rod $1 / 2$ in. in diameter and 2 in. long, containing up to 10,000 particles, is required to meet the defective particle fraction specification of $1 \times 10^{-3}$ or no more than ten defective particles per thousand.

The determination of the defective particle fraction was originally done by aqueous acid leaching, a process which required up to 80 hours to remove high-fired thoria exposed only through tiny cracks. In addition, the detection of particles with physically intact but permeable coatings was not possible. For these reasons the aqueous acid leach has been largely supplanted by the gaseous chlorine leach at $1000^{\circ} \mathrm{C}[1]$. In this method the fuel exposed by defective coatings is volatilized as the heavy metal chlorides which condense in the cooler parts of the apparatus and are 
collected and determined by routine methods. The amounts so determined indicate the probable number of defective particles in a sample.

With the Triso-coated particle, both the inner and outer pyrocarbon layers must be defective for chlorine leaching to remove fuel. An exposed but otherwise intact SiC layer is destroyed by chlorine. (The detection of a defect in a SiC layer itself may be done by burning off the outer pyrocarbon layers in air or oxygen, then treating the particles with mercury under pressure, and finally, by a radiographic technique, examining the underlying pyrocarbon layers for mercury incursions [2]). Carbide fuels react at relatively low temperatures (approximately $250^{\circ} \mathrm{C}$ ), and the chlorides formed sublime at higher temperatures (approximately $500^{\circ} \mathrm{C}$ for $\mathrm{UCl}_{4}$ $\mathrm{UCl}_{5}$ and approximately $750^{\circ} \mathrm{C}$ for $\mathrm{ThCl}_{4}$ ). Oxide fuels require the presence of carbon to drive the reaction beyond the oxychloride stage to the volatile chlorides. The carbon coating, in the presence of chlorine, reacts with the oxide fuel at the point of exposure. As the reaction proceeds, the kernel shrinks and consumes the coating at the point of contact, leaving an otherwise hollow carbon shell. The process requires a period of 6 to 16 hours to remove exposed fuel in a sample of loose particles.

Bonded fuel rods have had to be deconsolidated $[3,4]$ in order to determine the number of defective particles although a number of non-destructive methods have been suggested [5]. The chlorine leach method can be applied to the intact fuel rod, but depending solely on diffusion at $1000^{\circ} \mathrm{C}$ the action is slow. Complete removal of exposed fuel requires from 16 to 50 hours with periodic samplings to follow the degree of removal. An adaptation for use in a hot cell is described below under Low Temperature Chlorination. 
Chlorinations conducted at $1500^{\circ} \mathrm{C}$ showed marked improvement in rate of diffusion and removal of exposed fuel from intact rods. Heating was done by induction in a vertical system as described below under High Temperature Chlorination. Since thoria is the most refractory fuel, most experiments were conducted on specimens of Biso-coated $\mathrm{ThO}_{2}$.

\section{LOW TEMPERATURE CHLORINATION}

Chlorination of irradiated fuel rods in a hot cell is usually limited to resistance heating at $1000^{\circ} \mathrm{C}$. A system to operate at this temperature with adaptations for the hot cell is shown in Fig. 2. Two features are embodied in the system: (1) back-pressure from chlorine-absorbing traps is eliminated, thereby avoiding the need to grease ground joints; and (2) no metal parts are used, thereby eliminating the cumbersome drying train required to avoid chlorine corrosion problems. The chlorine was of $99.8 \%$ purity delivered through a Monel regulator, and the argon 99.9\%. A11 containing parts of the apparatus were of glass, quartz (fused silica), or Teflon. Stopcocks were of the Teflon-plug type, slightly lubricated with a fluorocarbon grease (Halocarbon Products Corp.). The Fischer and Porter flowmeters were Tri-Flat glass tubes with the designation FP-1/16-08-G-16 or -G-12 with sapphire floats. The Monel chlorine regulator, equipped with a Monel check valve and a Monel needle valve, was connected to the chlorine flowmeter by Teflon-lined neoprene tubing. All further flexible connections were made with 3/16-I.D. thin-walled Teflon tubing. The irradiated fuel rod was contained in a porous carbon (Carbocell) boat. (Previously it had been observed that particles chlorinated in a fused silica boat left impressions in the silica and showed a somewhat high defective particle fraction.) The carbon boats were preconditioned in chlorine to remove volatile 


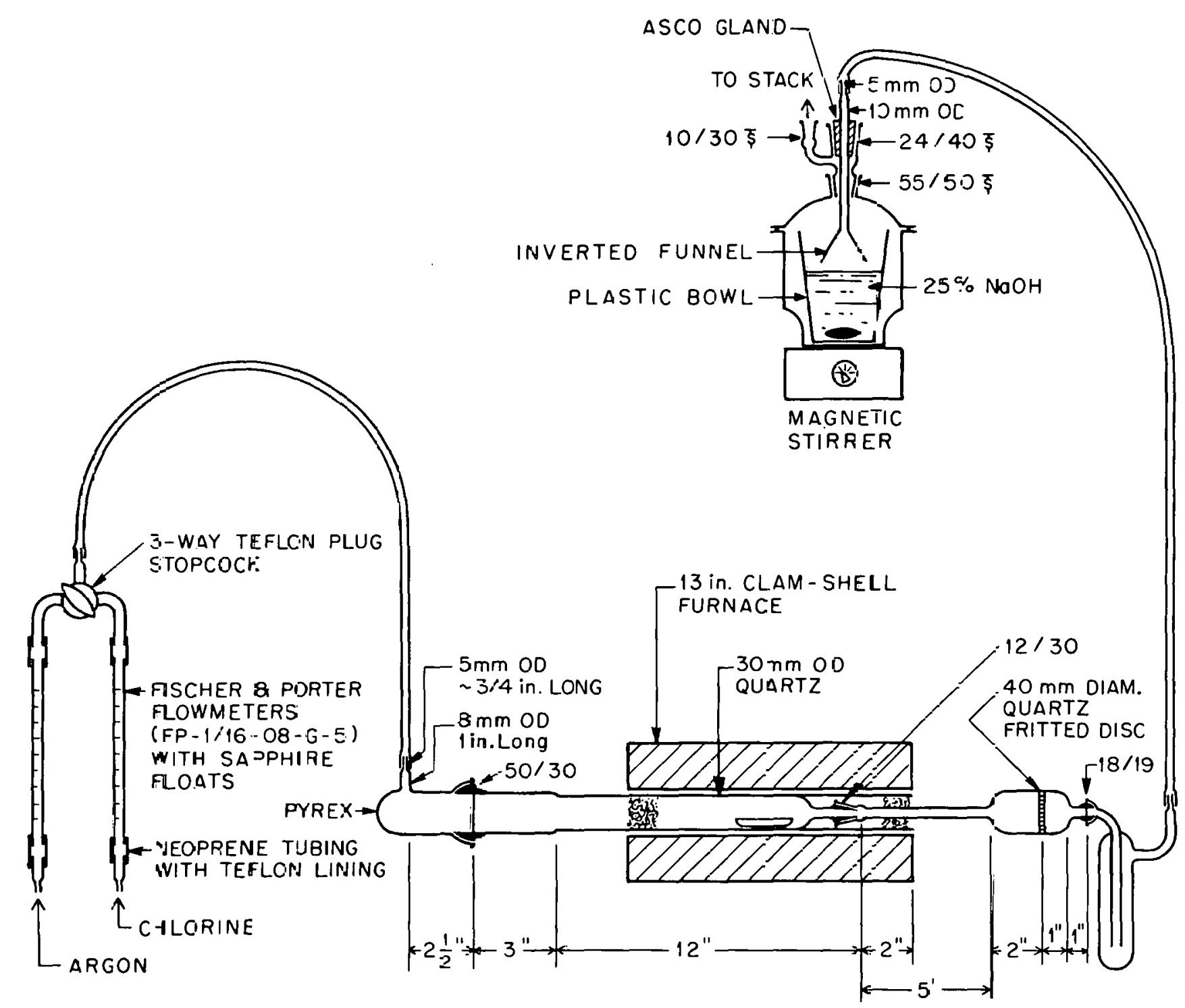

Fig. 2. Apparatus for Chlorine Leach at $1000^{\circ} \mathrm{C}$. 
and reactive components. Immediately beyond the boat an inner ground joint is sealed to the outer tube which extends further to the edge of the furnace. To the inner joint is attached the fused silica collector bulb containing a coarse fritted barrier. The space between the outer tube and inner tube at the edge of the furnace is filled with quartz wool to conserve heat, and a similar plug may be inserted in the main tube at the entrance to the furnace.

In operation the system is purged with argon, the temperature brought to $500^{\circ} \mathrm{C}$, and any vapors driven off. Then chlorine is admitted at $75 \mathrm{ml} /$ min and the argon flow reduced to $45 \mathrm{ml} / \mathrm{min}$. As the temperature is raised to $1000^{\circ} \mathrm{C}$, chlorides of uranium are evolved first and travel as far as the fritted barrier. The $\mathrm{ThCl}_{4}$, which is less volatile, condenses mostly in the inner tube. No uranium chlorides pass through the fritted barrier, the following trap being merely precautionary. The chlorine passes to a closed chamber where it is absorbed at the surface of a magnetically stirred pool of $25 \% \mathrm{NaOH}$ solution. At termination the fritted-bulb section is removed, washed with $1 \mathrm{~N} \mathrm{HCl}$, and dried with acetone. The thorium and uranium in the wash solution are determined by standard methods of analys is $[6,7]$. Where the use of carbon monoxide is feasible, the rate of removal of exposed fuel may be increased by providing readily available carbon for the reaction. The stoichiometry requires a mole ratio of $\mathrm{CO} / \mathrm{Cl}_{2}$ of $1: 1$, but the optimum ratio was found to be $2: 1$. These flows were obtained at 100 $\mathrm{ml} / \mathrm{min}$ for carbun monoxide and $50 \mathrm{ml} / \mathrm{min}$ for chlorine, eliminating the argon diluent. Chlorination of loose particles under these conditions is accomplished in 8 hours compared to 16 hours previously. 


\section{HIGH TEMPERATURE CHLORINATION}

Chlorination of $\mathrm{HTGR}$ fuel rods at $1500^{\circ} \mathrm{C}$ is accomplished in a vertical, water-jacketed, quartz furnace tube with heating provided by a $7.5 \mathrm{~kW}$ induction-heating unit of $500 \mathrm{kHz}$ nominal frequency. The significant part of the apparatus is shown in Fig. 3. With the exception of the furnace tube and sample holder, and the provision for separate entrances for chlorine and argon, all other arrangements are the same as in the low temperature system. The fuel rod is held in a hollow graphite holder (Fig. 4). In order to achieve a partial flow of chlorine through the microporous structure of the fuel rod, it is held firmly down upon its seat by a circular, slitted graphite wedge. Alternatively, the rod may be sealed in by packing the space between rod and holder with powdered Carbocel1, a granular, porous carbon formulation. The graphite holder is supported below by a 10-mm 0.D. quartz tube which projects into the holder $11 / 4 \mathrm{ill}$. dind through which chlorine passes to the rod above. A firm seat between quartz and graphite is obtained by twisting one piece within the other under slight pressure. The quartz tube passes below through a conventional gland device, providing support and permitting adjustment of the holder up or down to position rods of various lengths for optimum heating. The neoprene 0-rings of the gland are coated with fluorocarbon grease, and no deterioration has been observed. To chlorinate loose particles, the hole at the bottom of the sample space is covered with a porous carbon disc.

The system is purged with argon both within and outside the sample holder before heat is applied to a temperature of $1000^{\circ} \mathrm{C}$. Then by turning the three-way stopcock the argon is restricted to flowing outside the holder, and chlorine is now admitted inside the holder. The flows are adjusted 
ORNL-DWG. $75-1316$

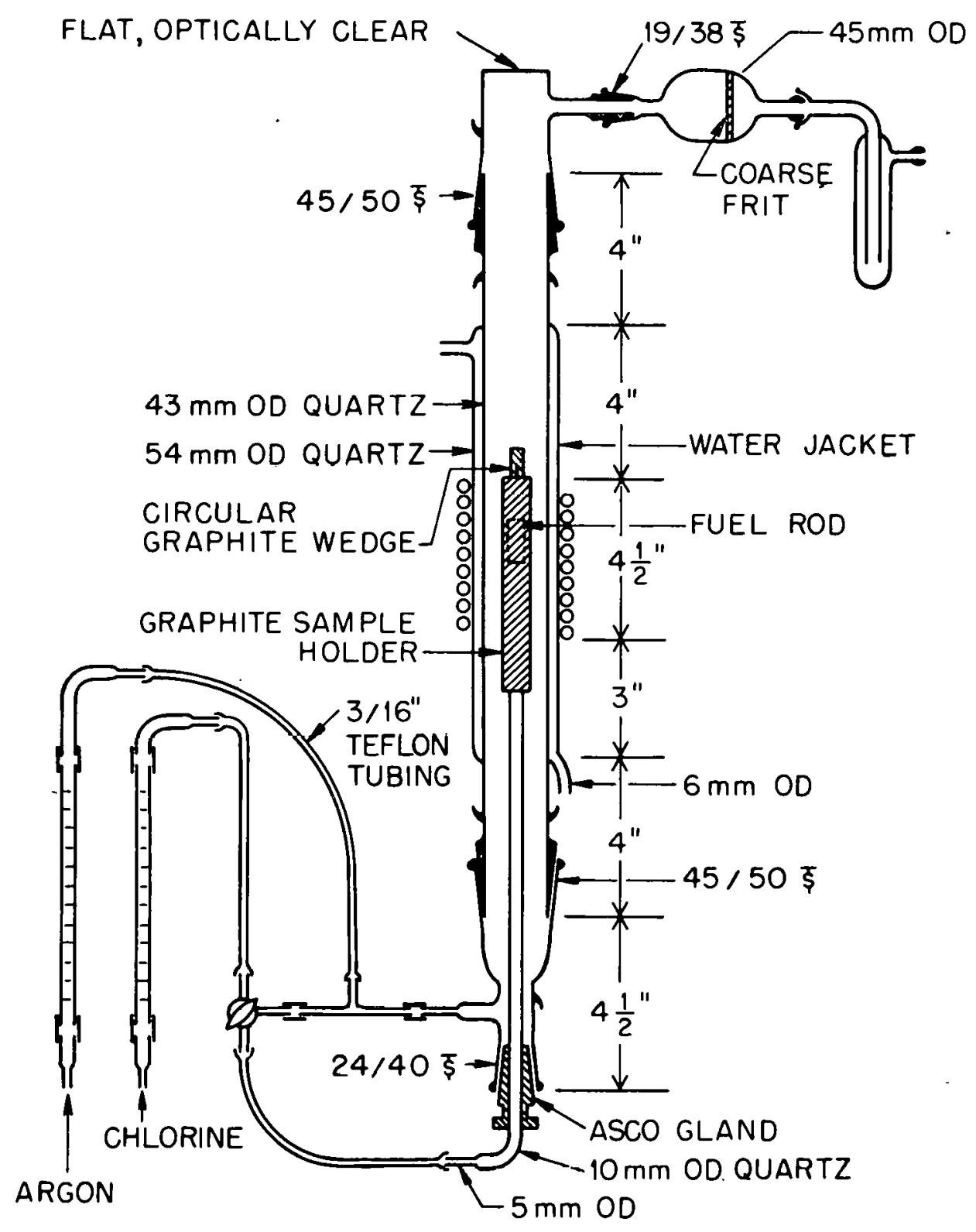

Fig. 3. Apparatus for Chlorine Leach at $1500^{\circ} \mathrm{C}$. 
ORNL - OWG. $75-1317$
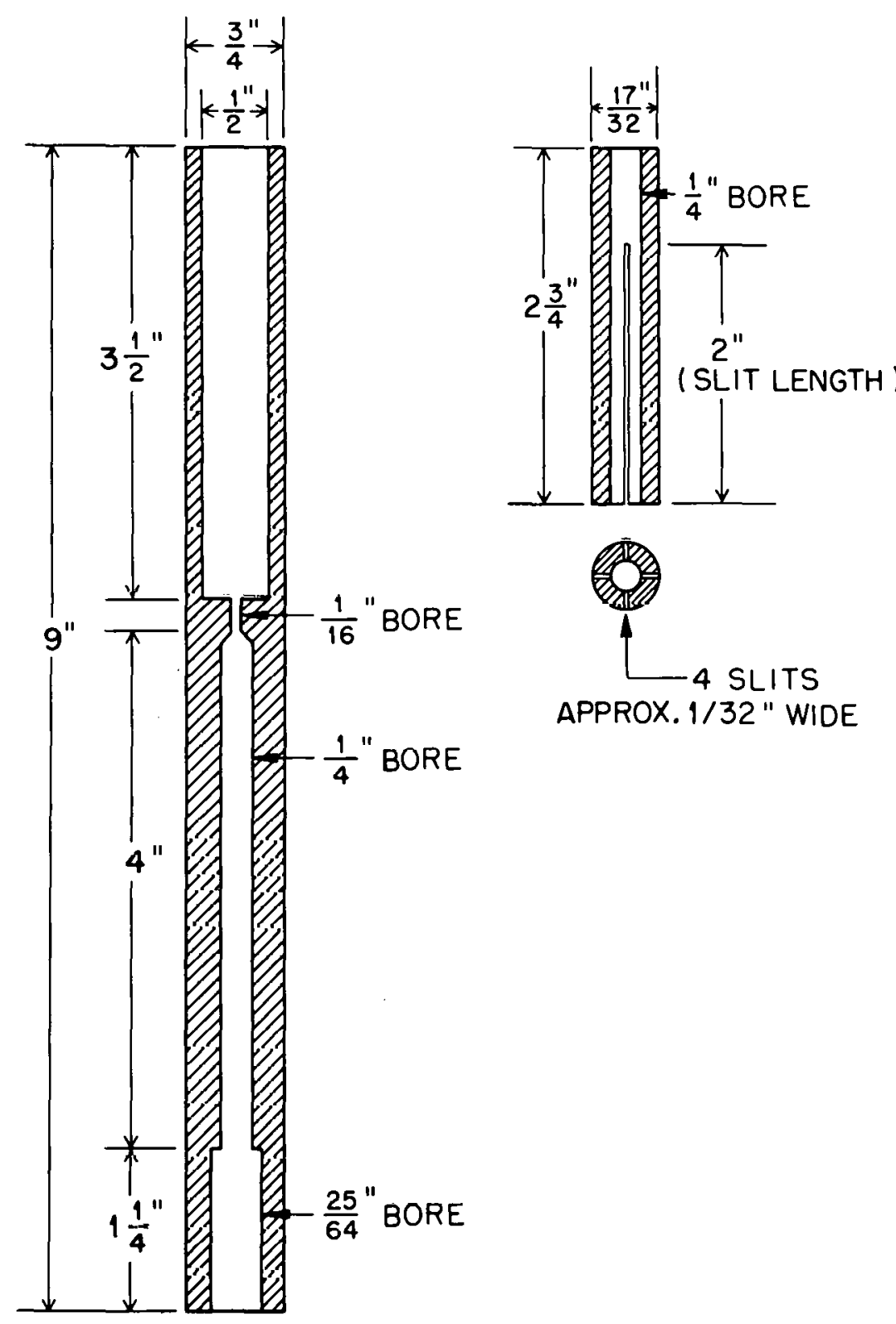

Fig. 4. Graphite Sample Holder for Rods or Loose Particles and Graphite Wedge. 
to the same rates as in the low-temperature system. Fumes of chloroorganic compounds, which may evolve at this time, are allowed to disperse before raising the temperature to $1500^{\circ} \mathrm{C}$ for the standard 2-hour chlorination period. At termination, cooling requires only 15 minutes while the entire system is being purged with argon. The fritted glass bulb and outlet cap are removed and washed with dilute $\mathrm{HCl}$. Finally the holder and sample are removed from below and the main tube washed with $\mathrm{HCl}$.

\section{RESULTS AND DISCUSSION}

The chlorination of loose fuel particles at $1000^{\circ} \mathrm{C}$ to determine the defective particle fraction is usually carried out for 16 hours with the removal of greater than $90 \%$ of exposed fuel. This technique has been used extensively to characterize Biso-coated $\mathrm{ThO}_{2}$ [8]. But when the method is applied to the bonded fuel rod, no specific time can be selected as indicating the removal of a definite fraction of exposed fuel. A definitive determination is only achieved by total removal requiring up to 50 hours with periodic sampling. Fig. 5 shows the course of removal of exposed fuel in four different rods.

When fuel rods were chlorinated at $1500^{\circ} \mathrm{C}$, however, the greatly increased diffusion produced a much more rapid removal of exposed fuel. Some results are given in Table 1 . Since fuel rods are approximately $40 \%$ void space, the possibility of forcing chlorine through the rod was considered. An apparatus (not shown) was constructed for use at $1000^{\circ} \mathrm{C}$ and designed to force the chlorine through the rod achieving so-called full flow-through. The result of a run on a representative standard fuel rod known to contain 10 cracked Biso-coated $\mathrm{ThO}_{2}$ particles is shown in Table 2. The apparatus, however, contained some metal parts and several water-cooling lines, making 


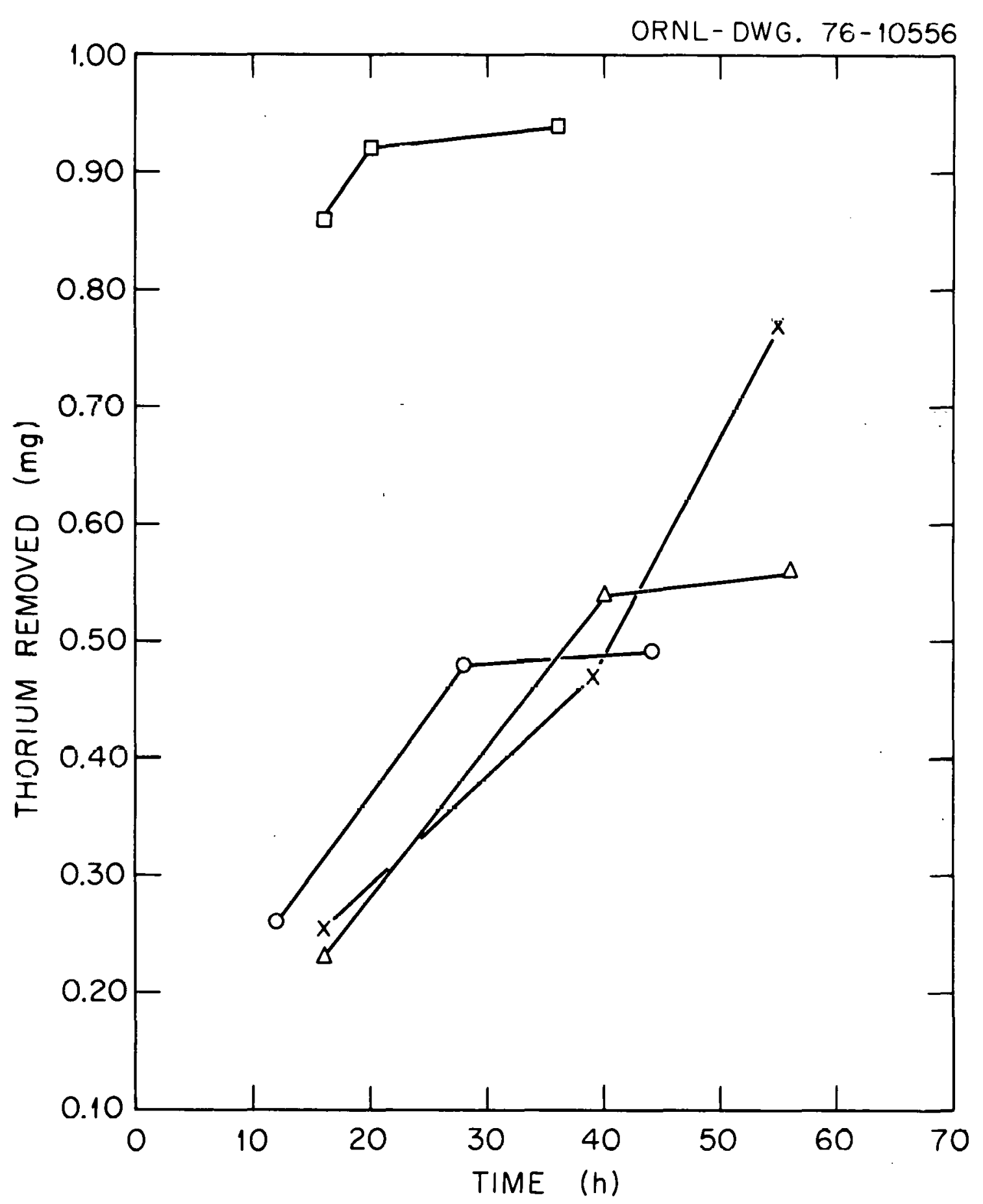

Fig. 5. Chlorination of Fuel Rods at $1000^{\circ} \mathrm{C}$. 
Table 1. Thorium Removal by Simple Diffusion at $1500^{\circ} \mathrm{C}(1 / 2 \times 2$ in. Rods $)$.

\begin{tabular}{lrr}
\hline & \multicolumn{2}{c}{ Thorium Removed $(\mu \mathrm{g})$} \\
\cline { 2 - 3 } Rod Number & First 3 Hours & Second 3 Hours \\
\hline 819 & 2,293 & 85 \\
820 & 44,500 & 1,660 \\
821 & 2,685 & 646 \\
822 & 23,833 & 1.35 \\
824 & 40 & 84 \\
825 & 16 & $<10$ \\
826 & $<10$ & $<10$ \\
827 & 1,235 & $<10$ \\
828 & 508 & 228 \\
829 & 1,756 & 287 \\
830 & 1,146 & 30 \\
\hline \hline
\end{tabular}

Table 2. Thorium Removal by Flow-Through Methods $(1 / 2 \times 2$ in. Rods $)$.

\begin{tabular}{ccc}
$\begin{array}{c}\text { Cumulative } \\
\text { Chlorination } \\
\text { Time }(\mathrm{h})\end{array}$ & $\begin{array}{c}\text { Ful1 Flow-Through } \\
1000^{\circ} \mathrm{C}(\% \text { Removed })\end{array}$ & $\begin{array}{r}\text { Modified Flow-Through } \\
1500^{\circ} \mathrm{C}(\% \text { Removed })\end{array}$ \\
\hline 1 & 79.5 & 95.2 \\
2 & 92.6 & 98.2 \\
3 & 100 & 99.4 \\
4 & - & 100 \\
\hline
\end{tabular}


it too cumbersome for routine use. Instead, a partial flow-through method for operation at $1500^{\circ} \mathrm{C}$ was adopted. It was achieved simply by pressing the fuel rod tightly down upon its seat with a circular graphite wedge (Fig. 4). It was more convenient, however, when a variety of sizes in rods had to be accommodated to dispense with wedges and to pack the space between rod and holder with the powdered Carbocell. A result from another standard fuel rod containing. 10 cracked particles run at $1500^{\circ} \mathrm{C}$ by the partial flow-through method is also shown in Table 2. Table 3 shows some results for rods from a variety of experimental fabrication runs. From these and similar data, a standard chlorination time of 2 hours was chosen for both rods and loose particles.

\section{CONCLUSION}

For both types of fuel samples, the rate of removal of the exposed heavy metal was not as consistent as desired. There are several possible explanations for the occasional erratic behavior. Some particles known by careful visual examination to have intact coatings were nevertheless permeable. This was often true for particles with coatings less than $35 \mu \mathrm{m}$ thick as illustrated in Fig. 6 , which shows the varied course of fuel removal after partial chlorination at $1000^{\circ} \mathrm{C}$. In bonded fuel rods, a particle may be so situated in the rod that the defect may be shielded by an exceptional barrier of the matrix, or the defect may be partially shielded by graphitized binder during fabrication of the rod. Despite these anomalies, greater than $80 \%$ of exposed fuel in defective particles is removed from fuel rods and made available for analys is in a 2-hour chlorination at $1500^{\circ} \mathrm{C}$. 
Table 3. Thorium Removal by Partial Flow-Through at $1500^{\circ} \mathrm{C}(1 / 2 \times 2$ in. Rods $)$.

\begin{tabular}{lcc}
\hline \hline & \multicolumn{2}{c}{ Thorium Removed $(\mu \mathrm{g})$} \\
\cline { 2 - 3 } Rod Number & 1797 & Second 2 Hours \\
\hline 7773 & 643 & 23 \\
8539 & 800 & 28 \\
9767 & 379 & 69 \\
9769 & 543 & 297 \\
9771 & 1570 & 72 \\
$3889 *$ & 3570 & 71 \\
$3897 *$ & 21000 & 76 \\
$4062 *$ & & 47 \\
\hline \hline
\end{tabular}

$\star 3 / 8 \times 1$ in. rods. 

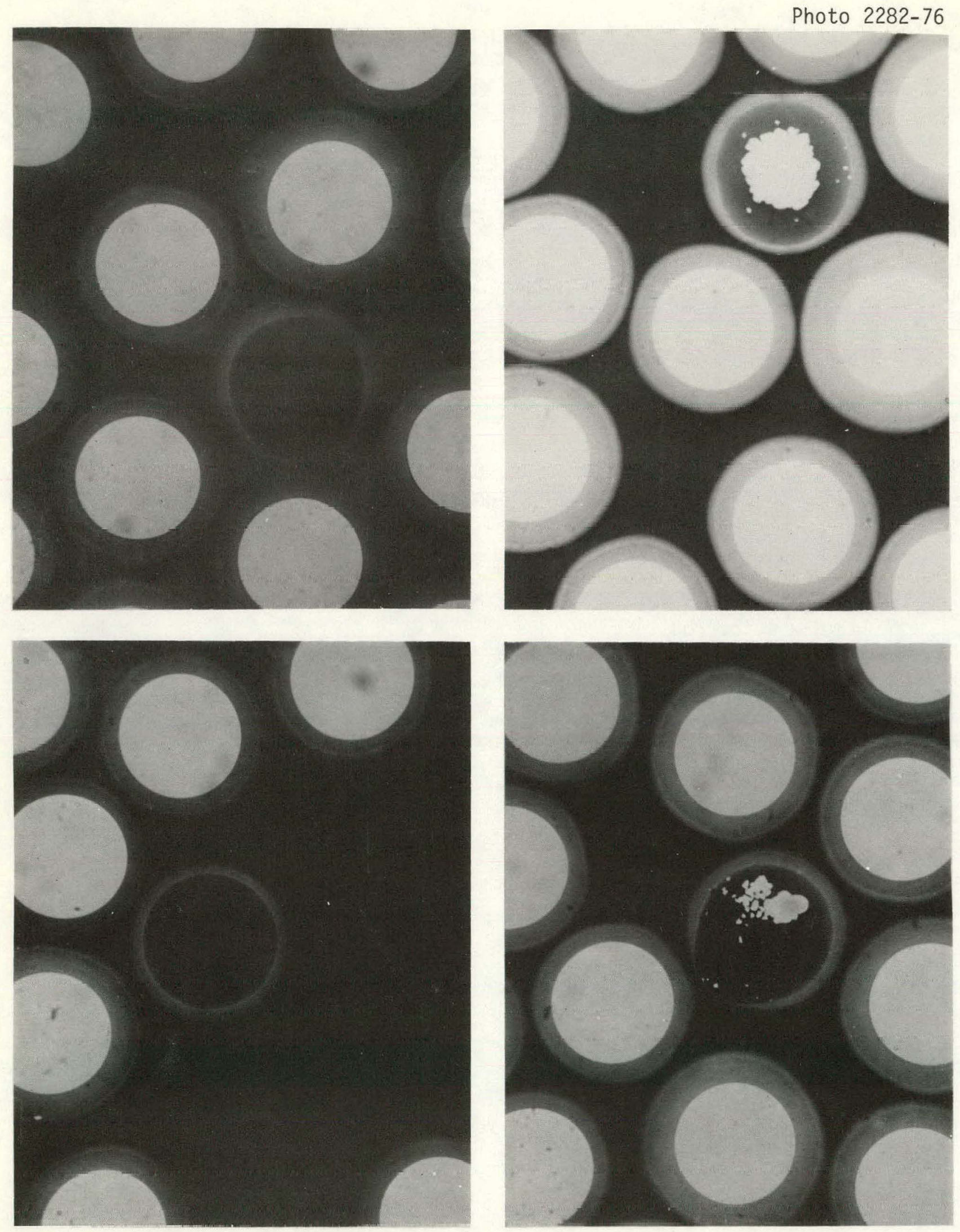

Fig. 6. Fuel Removal from Biso-coated $\mathrm{ThO}_{2}$ Particles with Permeable Coatings $(60 \mathrm{X})$. 
6. ACKNOWLEDGMENTS

Thanks are due W. J. Mason of the Metals and Ceramics Division for the microradiographs of fuel particles and W. R. Laing of the Analytical Chemistry Division for chemical analyses. 


\section{REFERENCES}

1. P. Koss and H. Bilstein, "Fabrication Methods and Evaluation of Uranium-Thorium Carbide Fuel for High-Temperature Gas-Cooled Reactors," in Proceedings of Second International Thorium Fuel Cycle Symposium, Gatlinburg, Tennessee, May 3-6, 1966, p. 268.

2. D. M. Hewette, III and W. R. Laing, "Detection of Defective SiC Layers in Coated Nuclear Fuel Particles," Nucl. Technol., 21, 149 (1974).

3. D. L. G. Smith, R. E. Siddal, H. Chapman, and A. E. E. Winfreth, "Application of Analytical Methods in the Control and Evaluation of Fuel Materials for the Dragon Reactor Experiment," in Proceedings of a Symposium on Analytical Methods in the Nuclear Fuel Cycle, International Atomic Energy Agency, Vienna, Nov. 29 to Dec. 3, 1971, p. 263.

4. H. Bilstein and K. Knotik, "Chemical and Electrochemical Methods for the Disintegration of Graphitic Nuclear Fuel Elements," Kerntechnik, 15, 554 (1973).

5. J. Holliday and M. S. T. Price, "Non-destructive Testing of Coated Particle Fuels," in Report of a Panel Sponsored by the International Atomic Energy Agency Held in Vienna, November 29 to December 3, 1971, p. 315 .

6. S. B. Savin, "Analytical Applications of Arsenazo 111-11, Uetërminat.inn of Thorium, Uranium, Protactinium, Neptunium, Hafnium, and Scandium," Talanta II, 1 (1964).

7. J. C. White, "The Use of Trialkylphosphine Oxides as Extractants in the Fluorometric Determination of Uranium," USAEC Report UKNL-2161, Oak Ridge National Laboratory, November 1956.

8. W. J. Lackey, J. D. Sease, D. A. Lostānz̄ó, and D. E. LaVdlle, "Improved Coating Process for High-Temperature Gas-Cooled Reactor Fuel," Trans. Amer. Nucl. Soc., 22, 194 (1975). 
ORNL/TM-5483

Dist. Category UC-77

INTERNAL DISTRIBUTION

1. P. Angelini

2. R. L. Beatty

3. R. A. Bradley

4. A. J. Caputo

5. J. A. Carpenter

6. J. H. Coobs

7. L. T. Corb in

8-11. D. A. Costanzo

12. R. G. Donnelly

13. W. P. Eatherly

14. R. L. Hamner

15. F. J. Homan

16. J. D. Jenkins

17. D. R. Johnson

18. M. J. Kania

19-20. P. R. Kasten

21. W. J. Lackey, Jr.

22. D. E. LaValle

23. T. B. Lindemer

24. E. L. Long, Jr.

25-26. A. L. Lotts
27. J. E. Mack

28. A. P. Malinauskas

29. M. T. Morgan

30. K. J. Notz

31. A. R. 01sen

32. W. H. Pech in

33. W. D. Shults

34. D. P. Stinton

35. R. R. Suchomel

36. V. J. Tennery

37. T. N. Tiegs

38. J. E. Van Cleve, Jr.

39. J. R. Weir

40. R. P. Wichner

41-43. Central Research Library

44. Document Reference Section

45-54. Laboratory Records Department

55. Laboratory Records Department, ORNL RC

56. ORNL Patent Office

\section{EXTERNAL DISTRIBUTION}

57-58. ERDA DIVISION OF NUCLEAR FUEL CYCLE AND PRODUCTION, Washington, D. C. 20545

Director

59-60. ERDA DIVISION OF REACTOR DEVELOPMENT AND DEMONSTRATION, Washington, D. C. 20545 Attn: Directur

61-62. ERDA OAK RIDGE OPERATIONS OFFICE, P. O. BOX E, Oak Ridge, Tennessee 37830 Director, Reactor Division Research and Technical Support Division

63-233. ERDA TECHNICAL INFORMATION CENTER, Office of Information Services, P. 0. Box 62, Oak Ridge, Tennessee 37830 For Distribution as shown in TID-4500 Distribution Category, UC-77 (Gas-Cooled Reactor Technology)

234-271. ERDA Exchange Agreements with Germany and Dragon Project. 